\title{
Unintentional transport of fungi propagules to Antarctic biome and the ability to develop at low temperatures ${ }^{\star}$
}

\author{
Niezamierzony transport propaguli grzybów pleśniowych do biomu Antarktyki a zdolność \\ rozwoju w niskich temperaturach
}

\author{
Anna Augustyniuk-Kram \\ Institute of Ecology and Bioethics, Cardinal Stefan Wyszyński University in Warsaw, Poland \\ ORCID: https://orcid.org/0000-0002-1904-9766•a.kram@uksw.edu.pl
}

\begin{abstract}
Filamentous fungi relatively easily disperse and colonize a variety of substrates, inhabiting various, often extreme environments. Therefore, they spread all over the world. The purpose of the research was to determine whether the propagules of filamentous fungi brought (accidentally transported) into the Antarctic biome by tourists and members of scientific expeditions are capable of developing at low temperatures. In the studies were used seven isolates of fungi: Penicillium sp., Aspergillus flavus, Alternaria alternata, Cladosporium cladosporioides, Trichoderma viride, Geotrichum candidum and Botrytis cinerea. The isolates came from samples collected from tourists and members of scientific expeditions arriving at the Henryk Arctowski Polish Antarctic Station on King George Island in the South Shetland archipelago. Fungal growth was measured at $0,5,10,22^{\circ} \mathrm{C}$ (as a control) and $10^{\circ} \mathrm{C}$, but after having frozen inoculum at $-15^{\circ} \mathrm{C}$ for a period of 7 days. Penicillium sp., Alternaria alternata, Cladosporium cladosporioides, Trichoderma viride, Geotrichum candidum and Botrytis cinerea were found to be capable of growing at low temperatures (5 and $10^{\circ} \mathrm{C}$ as well as after one freezing cycle, down to $-15^{\circ} \mathrm{C}$ and thawing, up to $+10^{\circ} \mathrm{C}$ ). They did not produce a macroscopically visible mycelium at temp. $0^{\circ} \mathrm{C}$, however, it was not a lethal temperature for them, as when they were transferred to higher temperatures, they continued to develop even after a fairly long time following the beginning of the experiment. The most vulnerable was Aspergillus flavus. At lower temperatures (from about to $5^{\circ} \mathrm{C}$ ) it did not develop, while freezing and thawing were lethal for this species. Some species (G. candidum, T. viride and B. cinerea), despite the development of mycelium, did not produce spores at lower temperatures.
\end{abstract}

Keywords: the Antarctic, microscopic fungi, foreign species

Streszczenie: Obecność człowieka w Antarktyce to przede wszystkim działalność naukowa, ale również w ostatnim czasie wzmożony ruch turystyczny. Sprzyja to inwazji obcych gatunków flory i fauny, a także mikroorganizmów, mogących zagrażać gatunkom rodzimym. Grzyby pleśniowe będące przedmiotem badań zaliczane są do organizmów kosmopolitycznych, łatwo rozprzestrzeniających się i zasiedlających różnorodne środowiska, w tym również ekstremalnie zimne, takie jak rejony polarne. Organizmy te, by skutecznie skolonizowaćnowe środowisko opróczżywotnych propagul i skutecznych mechanizmów transportu muszą byćzdolne do wzrostu i reprodukcji w ekstremalnych warunkach. Celem badań było określenie czy propagule grzybów pleśniowych zawleczone (przypadkowo przetransportowane) do biomu Antarktyki przez turystów i członków wypraw naukowych są zdolne do rozwoju w niskich temperaturach. Badane grzyby (Penicillium sp., Alternaria alternata, Cladosporium cladosporioides, Trichoderma viride, Geotrichum candidum i Botrytis cinerea) były zdolne do rozwoju w niskich temperaturach $\left(5 \mathrm{i} 10^{\circ} \mathrm{C}\right.$ oraz po jednym cyklu zamrożenia do $-15^{\circ} \mathrm{C}$ i odmrożenia do $+10^{\circ} \mathrm{C}$ ). Nie wytwarzały makroskopowo widocznej grzybni w temp. $0^{\circ} \mathrm{C}$, lecz nie była to dla nich temperatura letalna, ponieważ po przeniesieniu do wyższych temperatur podejmowały wzrost nawet po dosyć długim czasie od rozpoczęcia eksperymentu Najbardziej wrażliwy okazał się A. flavus. Przy niższych temperaturach (od 0 do $5^{\circ} \mathrm{C}$ ) nie rozwijał się, natomiast zamrożenie i odmrożenie było dla tego gatunku letalne. Niektóre gatunki (G. candidum, T. viride i B. cinerea) mimo rozwoju grzybni, w niższych temperaturach nie produkowały zarodników.

Słowa kluczowe: Antarktyka, grzyby mikroskopowe, gatunki obce

\footnotetext{
* This article was originally published in Polish as Augustyniuk-Kram, Anna. 2016. "Niezamierzony transport propaguli grzybów pleśniowych do biomu Antarktyki a zdolność rozwoju w niskich temperaturach." Studia Ecologiae et Bioethicae 14(4): 149-166. The translation of the article into English was financed by the Ministry of Science and Higher Education of the Republic of Poland as part of the activities promoting science - Decision No. 676/P-DUN/2019 of 2 April 2019. Translation made by GROY Translations.
} 


\section{Introduction}

Because of its geographical isolation and extremely unfavourable climatic conditions, Antarctica is the slowest colonised by foreign plant and animal species area on Earth. Despite that, in the recent years, there has been seen a sharp increase in the number of new species appearing in this area, primarily vascular plants, but also invertebrates (Gremmen, and Smith 1999; Convey et al. 2010; Hughes, and Worland 2010). This is influenced by increased human activity, especially in the subantarctic islands region, as well as the climate change observed over recent years in the area (Kejna 2008; Olech et al. 2013; Huiskes et al. 2014). In addition to the natural mechanisms and ways of dispersion in various species, most alien to Antarctic plants and animals, as well as microorganisms, are transported along with man, who is the most efficient and fastest vector of exotic species for the region (Whinam, Chilcott, and Bergstrom 2005; Lityńska-Zając et al. 2012).

Human activity in the Antarctic is primarily scientific, located around research stations and associated logistics, i.e. transport of vast quantities of equipment and cargo, including food, with which propagules of non-native species of plants, animals and microorganisms are accidentally transported (Hughes et al. 2011; Augustyniuk-Kram et al. 2013; Chwedorzewska et al. 2013b; Huiskes et al. 2014; Molina-Montenegro et al. 2014). In recent years there has also been a significant increase in tourism, which is mainly concentrated in West Antarctica, where, among others, Henryk Arctowski Polish Antarctic Station is localized (Chwedorzewska, and Korczak 2010). So far, the greatest intensity of tourist traffic was recorded in season 2007/2008, where in summer alone Antarctica was visited by more than 46 thousand tourists, not including scientific expeditions. In season 2015-2016 this number is also estimated to be over 40 thousand (IAATO 2016). Such a large increase of tourist traffic encourages the invasion of alien species of flora and fauna, as well as microorganisms that can be a threat to native species (Chwedorzewska et al. 2013a).

Mould fungi (filamentous fungi), which constitute the subject of the presented research, relatively easily spread in the environment, colonising various types of base surfaces and frequently enduring extreme environmental conditions. As a result, they spread throughout the world (Ruisi et al. 2007). Most of the filamentous fungi found in Antarctica are cosmopolitan species. However, the ones that were brought there, most often cannot thrive in its climate, whereas native fungi are well-adapted and can develop even at low temperatures and on nutrient-poor substrates. They are distinguished by their shortened life cycle and fast (i.e. occurring in a short time) sporulation or production of periodically sterile mycelium (Ruisi et al. 2007). The fungi found in various ecosystems of Antarctica are adapted to low temperatures, recurring freezing and thawing, low availability of water, osmotic stress, dehydration, low availability of nutrients and high UV radiation (Ruisi et al. 2007). Microorganisms living in such extreme conditions develop special adaptations at every level of cell organization. The adaptations comprise, among other things: modification of fatty acids composition in cell membranes, an adaptation of enzymes to low temperatures, increased synthesis of sugars stabilizing cell membranes and preventing cell dehydration, increased synthesis of polyols - glycerol and mannitol, sustaining turgor in cells, synthesis of unique proteins absent in other microorganism groups (ice nucleation proteins, antifreeze proteins, cold shock proteins) decreasing water coagulation point, synthesis of dark pigments (melanin) in a mycelium, protecting against strong UV radiation (Turkiewicz 2006; Russel 2008; Maggi et al. 2013).

The purpose of the research was to determine whether the propagules of mould fungi brought (accidentally transported) into the Antarctic biome by tourists and members of scientific expeditions are capable of developing at low temperatures. 


\section{Materials and methods}

Seven isolates of filamentous fungi were used for the study: Penicillium sp. (Link), Aspergillus flavus (Link), Alternaria alternata (Fr.) Keissl, Cladosporium cladosporioides (Fresen.) G.A. de Vries, Trichoderma viride Pers., Geotrichum candidum (Link) and Botrytis cinerea Pers. The isolates were derived from dust samples collected from clothes, shoes, hand luggage of tourists and members of scientific expeditions arriving at the Henryk Arctowski Polish Antarctic Station (King George Island, South Shetland Islands, $62^{\circ} 09^{\prime} \mathrm{S}, 58^{\circ} 28^{\prime} \mathrm{W}$ ) (Augustyniuk-Kram et al. 2013).

The selected isolates were plated with a standardized sterile inoculation loop $(\varnothing 0.1 \mathrm{~mm})$ on an agar plate and incubated for 14 days at the following temperatures: $0,5,10,22^{\circ} \mathrm{C}$ (control), and $-15^{\circ} \mathrm{C}$ for 7 days (freezing rate $1^{\circ} \mathrm{C} / \mathrm{min}$.). Cultures from $-15^{\circ} \mathrm{C}$ were transferred to $+10^{\circ} \mathrm{C}$ for the next 7 days so that the total incubation time was also 14 days. Two different culture media were used: Sabouraud Agar with chloramphenicol (SAB) and Rose Bengal Agar (RBA). Both media are used to selectively isolate and cultivate fungi from environmental and food samples. Measurements of the colony's diameter were made every 2-3 days. The experiment was performed in 5 replications for each medium and temperature. If the inoculum did not show development at the temperatures tested, the plates were gradually transferred to higher temperatures.

After 14 days of culture, the intensity of sporulation was also determined. Three culture plates were randomly selected from each temperature and medium. From each selected agar plate, in three randomly chosen places, fragments of the mycelium were cut with a cork borer $(\varnothing 1 \mathrm{~cm})$ and transferred to Falcon tubes with Triton-X $(0.5 \mathrm{ml} / \mathrm{l})$ solution to facilitate the removal of spores from the mycelium's surface. The test tubes were shaken at maximum RPM on a Vortex type shaker for 5 minutes. The number of spores per $\mathrm{ml}$ of the suspension was determined by the use of Thoma counting chamber.
The significance of differences between the average size of colonies after 14 days of cultivation in the tested media at particular temperatures was checked with the non-parametric Mann-Whitney test at the significance level of $\mathrm{p}<0.05$.

The effect of temperature on the sporulation intensity of the examined fungi was tested using the non-parametric Kruskal-Wallis test. The significance of differences between the average spore number at tested temperatures was verified using Tukey's test at the significance level of $\mathrm{p}<0.05$. For statistical calculations, the computer program Statistica, version 6.0 was used (StatSoft 1984-2001).

\section{Results}

All the fungi studied did not develop at a temperature of $0^{\circ} \mathrm{C}$. Aspergillus flavus was the only one not to grow at $5^{\circ} \mathrm{C}$. Species A. flavus and G. candidum also did not develop after the inoculum was temporarily frozen at a temperature of $-15^{\circ} \mathrm{C}$ and subsequently transferred to $+10^{\circ} \mathrm{C}$ (Fig. 1).

The growth of the majority of fungi studied was influenced by the type of medium. In general, fungi on the Sabouraud (SAB) medium showed better development than on those on the Bengal Rose one (RBA) (Fig. 1). In control $\left(22^{\circ} \mathrm{C}\right)$, C. cladosporioides, A. alternata and B. cinerea achieved significantly better growth on the Sabouraud medium. G. candidum species was the only one to display improved development on medium with Bengal rose. At a temperature of $5^{\circ} \mathrm{C}$ significantly better growth on Sabouraud medium was achieved by Penicillium sp., A. alternata and $C$. cladosporioides. At a temperature of $10^{\circ} \mathrm{C}$ better growth on the Sabouraud medium has also reached $T$. viride. At a temperature of $10^{\circ} \mathrm{C}$, however, after previous freezing of the inoculum, the species $A$. alternata and T. viride significantly improved growth achieved on the Bengal Rose medium (Fig. l).

Growth dynamics of the fungi studied were very similar both on the Sabouraud and the Bengal Rose medium, therefore the figure (Fig. 2) presents only the growth 
Penicillium sp.

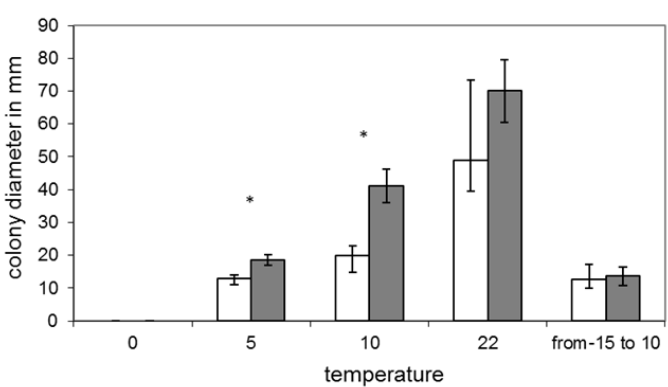

Alternaria alternata

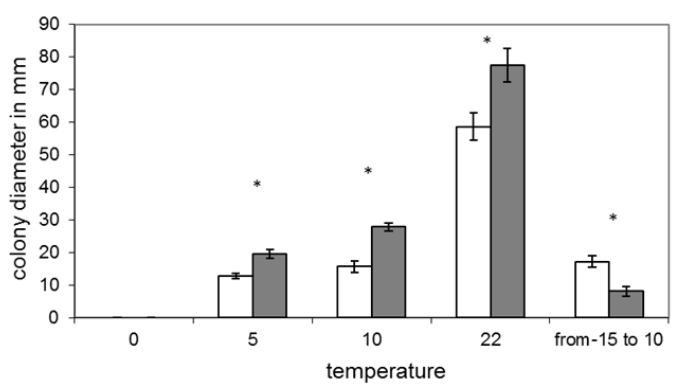

Trichoderma viride

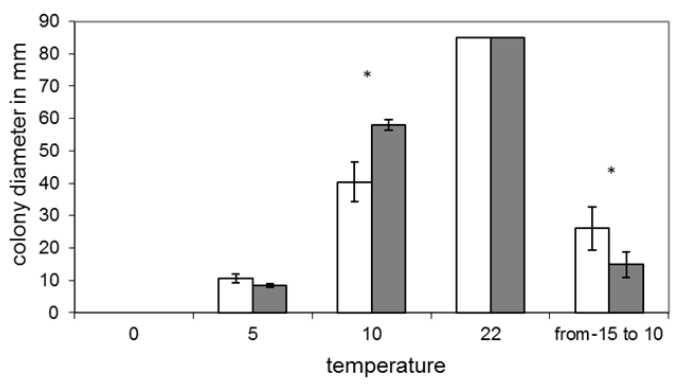

Botrytis cinerea

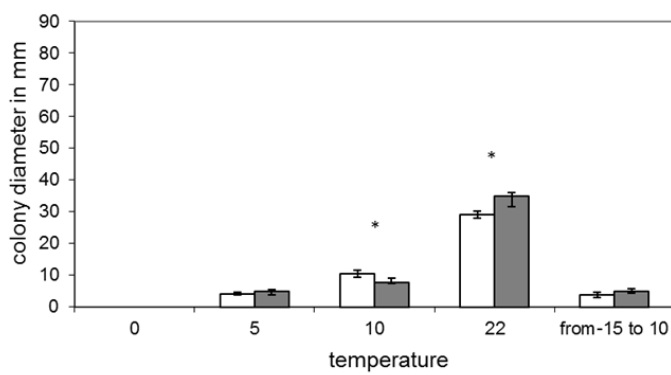

Aspergillus flavus

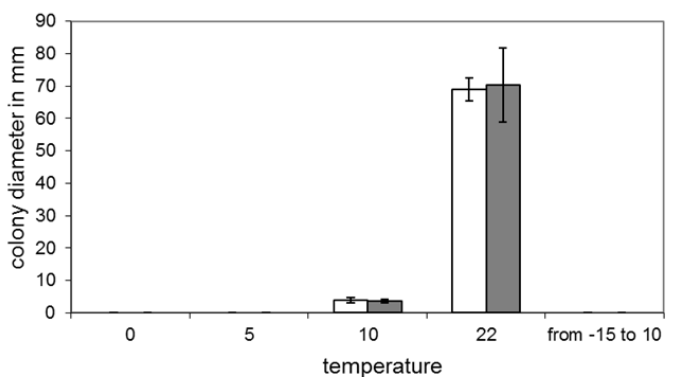

Cladosporium cladosporoides

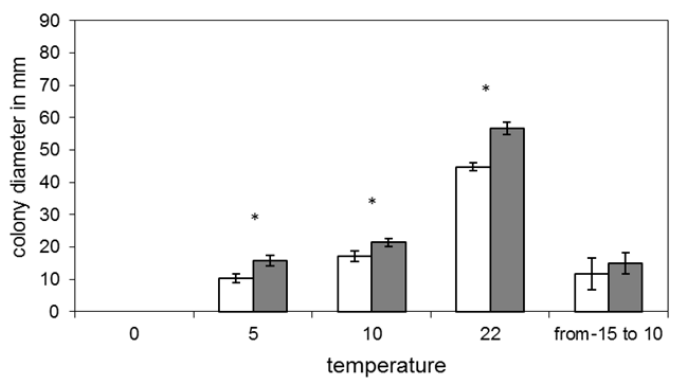

Geotrichum candidum

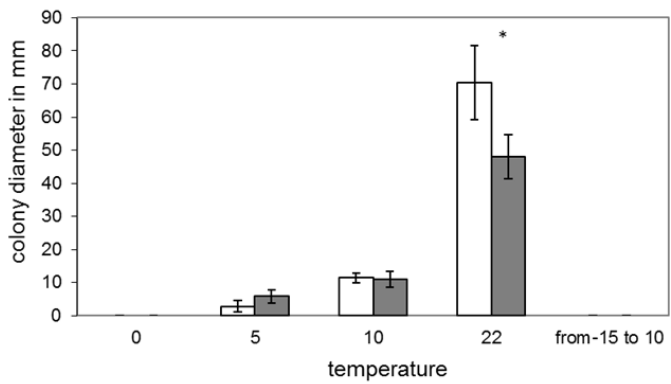

口RBA

口SAB

Fig. 1. Growth of the fungi tested at $0,5,10,22$ and $-15 /+10^{\circ} \mathrm{C}$ on the Bengal Rose agar (RBA) and Sabouraud agar (SAB) (* - statistically significant differences). 


\section{Penicillium sp.}

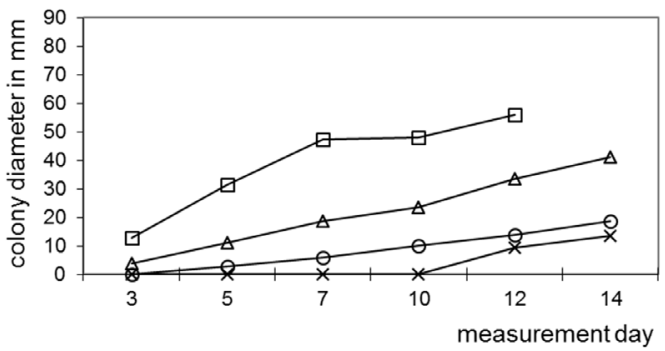

Alternaria alternata

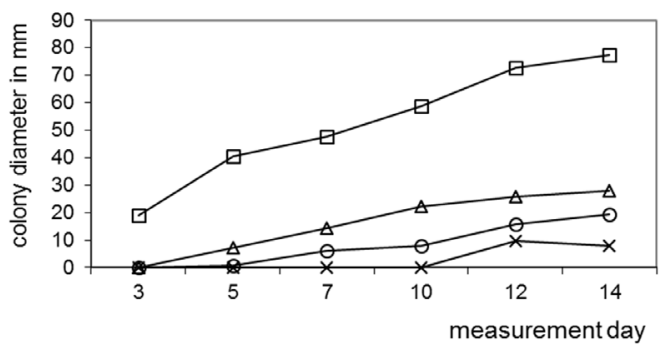

Trichoderma viride

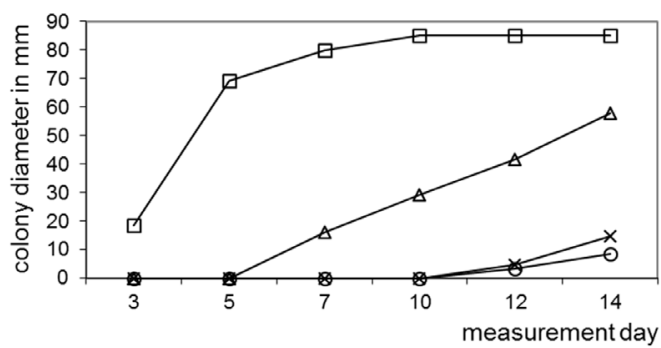

Botrytis cinerea

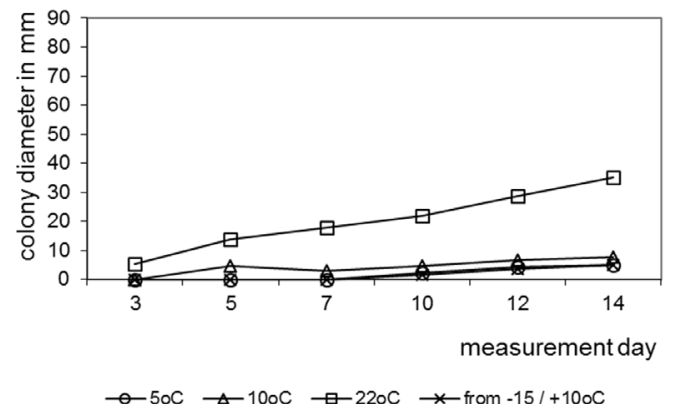

Aspergillus flavus

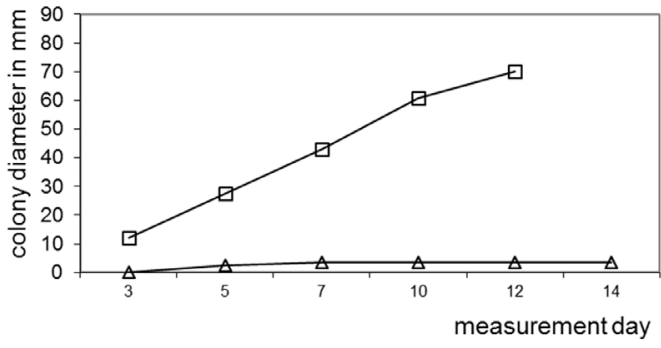

Cladosporium cladosporoides

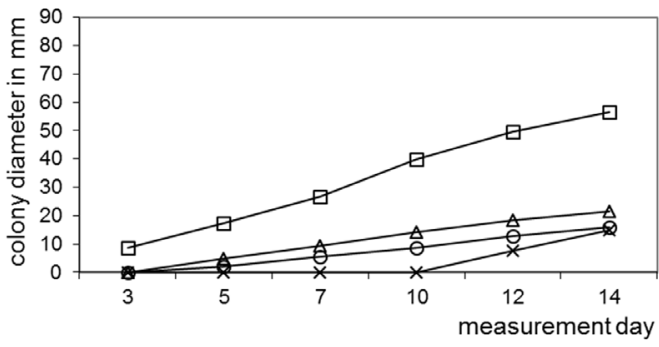

Geotrichum candidum

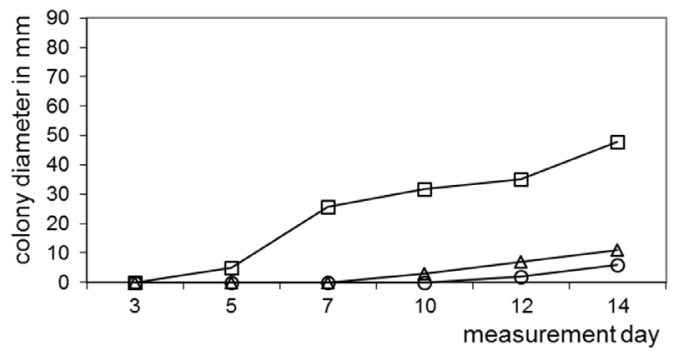

Fig. 2. Growth dynamics of the tested fungi depending on the temperature on the Sabouraud medium. 


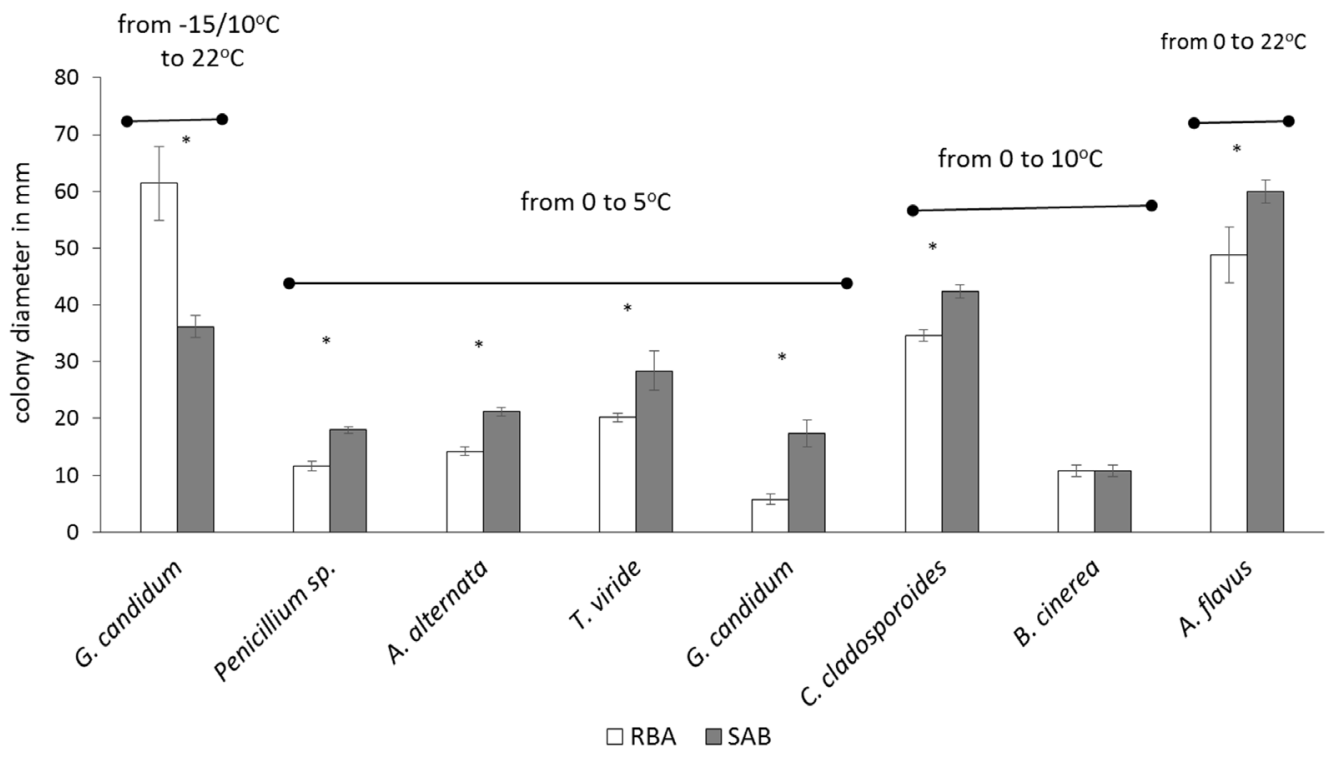

Fig. 3. Growth of the tested fungi at 5,10 or $22^{\circ} \mathrm{C}$, after transferring from temperatures where they did not show any development (* - statistically significant differences).

rate on the Sabouraud medium. None of the fungi tested at 5,10 and $-15 /+10^{\circ} \mathrm{C}$ achieved a growth measurement similar to that of control $\left(22^{\circ} \mathrm{C}\right)$ on the last day. All fungi tested (except T. viride) did not show a significant difference in the initial growth stage, up to 5-7 day. Only after 7 days that disproportions became apparent. The growth rate in the control was much faster than in the other variants of the experiment. After temporal freezing of the inoculum at $-15^{\circ} \mathrm{C}$ for 7 days, followed by thawing and incubation at $+10^{\circ} \mathrm{C}, A$. flavus and G. candidum did not resume growth. In the remaining cases, the inoculum resumed growth on the 4th-5th day after thawing, however, the colonies did not achieve the diameter they had reached at $10^{\circ} \mathrm{C}$ (in a no pre-freezing variant). Compared to $10^{\circ} \mathrm{C}$, the previously frozen ones were about 2 to 4 times smaller (Fig. 2). Fungi that did not grow at $0^{\circ} \mathrm{C}$, after being transferred to higher temperatures began to develop (Fig. 3). Fungi Penicillium sp., A. alternata, T. viride and G. candidum began their growth after being transferred to temperature of $5^{\circ} \mathrm{C}$. Fungi C. cladosporioides and $B$. cinerea resumed development after being transferred to the temperature of $10^{\circ} \mathrm{C}$, while $A$. flavus did so only at the control temperature of $22^{\circ} \mathrm{C}$. Of the two species that did not grow after the freezing of inoculum and subsequent transfer to the $10^{\circ} \mathrm{C}$, i.e. G. candidum and A. flavus, only G. candidum resumed its growth at $22^{\circ} \mathrm{C}$ (Fig. 3).

The sporulation of the examined fungi was, in most cases, the most abundant at $22^{\circ} \mathrm{C}$ (control). Only A. alternata on both media produced spores better at a temperature of $10^{\circ} \mathrm{C}$ without pre-freezing, as well as in combination with freezing (Table l). At a temperature of $10^{\circ} \mathrm{C}$, after previous freezing, $T$. viride and $B$. cinerea did not produce spores on both media, while $G$. candidum - at a temperature of 5 and $10^{\circ} \mathrm{C}$ (Table l).

\section{Discussion}

Among the basic factors limiting the development of microorganisms are both high and low temperatures. Fungi can grow in a wide temperature range (Domsch, and Gams 1972). The polar, Antarctic regions belong to the so-called extreme environments for microbial growth. Low temperatures, periods of sudden freezing and thawing, low water activity, and high doses 
Table 1. Sporulation of selected fungal species at different temperatures on the Sabouraud $(\mathrm{SAB})$ and Bengal Rose (RBA) medium (average value $\times 10^{6} \mathrm{spores} / \mathrm{ml}$; values in rows marked with the same letters no differ statistically significantly).

\begin{tabular}{lccccc}
\hline \multirow{2}{*}{ Species } & Medium & \multicolumn{4}{c}{ Temperature } \\
\cline { 3 - 6 } Penicillium sp. & & $5^{\circ} \mathrm{C}$ & $10^{\circ} \mathrm{C}$ & $22^{\circ} \mathrm{C}$ & $-15 /+10^{\circ} \mathrm{C}$ \\
\hline \multirow{2}{*}{ Aspergillus flavus } & $\mathrm{SAB}$ & $14^{\mathrm{b}}$ & $44^{\mathrm{a}}$ & $60^{\mathrm{a}}$ & $12^{\mathrm{b}}$ \\
& $\mathrm{RBA}$ & $27^{\mathrm{A}}$ & $55^{\mathrm{A}}$ & $34^{\mathrm{A}}$ & $14^{\mathrm{B}}$ \\
\hline \multirow{2}{*}{ Cladosporium cladosporioides } & $\mathrm{SAB}$ & - & $18^{\mathrm{a}}$ & $51^{\mathrm{b}}$ & - \\
& $\mathrm{RBA}$ & - & $20^{\mathrm{A}}$ & $29^{\mathrm{A}}$ & - \\
\hline \multirow{2}{*}{ Alternaria alternata } & $\mathrm{SAB}$ & $0.42^{\mathrm{a}}$ & $0.39^{\mathrm{a}}$ & $0.67^{\mathrm{a}}$ & $0.50^{\mathrm{a}}$ \\
& $\mathrm{RBA}$ & $0.55^{\mathrm{A}}$ & $0.17^{\mathrm{A}}$ & $1.2^{\mathrm{A}}$ & $0.50^{\mathrm{A}}$ \\
\hline \multirow{2}{*}{ Trihoderma viride } & $\mathrm{SAB}$ & $0.58^{\mathrm{a}}$ & $1.0^{\mathrm{a}}$ & $0.86^{\mathrm{a}}$ & $2.2^{\mathrm{b}}$ \\
& $\mathrm{RBA}$ & $0.53^{\mathrm{C}}$ & $6.0^{\mathrm{A}}$ & $0.92^{\mathrm{C}}$ & $2.6^{\mathrm{B}}$ \\
\hline \multirow{2}{*}{ Botritis cinerea } & $\mathrm{SAB}$ & $0.36^{\mathrm{a}}$ & $0.53^{\mathrm{a}}$ & $0.61^{\mathrm{a}}$ & $0.0^{\mathrm{a}}$ \\
\hline \multirow{2}{*}{ Geotrichum candidum } & $\mathrm{RBA}$ & $0.28^{\mathrm{B}}$ & $0.22^{\mathrm{B}}$ & $1.2^{\mathrm{A}}$ & $0.0^{\mathrm{B}}$ \\
\hline
\end{tabular}

of UV radiation are often deadly to microorganisms not adapted to such conditions. The temperatures in the presented experiment were chosen to simulate the conditions that fungi (spores) could be in at the time of their introduction.

The largest tourist traffic and period of increased influx of research teams is the austral summer, which lasts from December to March (IAATO 2016). The movement is mostly concentrated in areas of the Antarctic islands, where climatic conditions are not as severe as in the continental part. During the austral summer, the average air temperature in the vicinity of the Arctowski station (from where the tested fungi were isolated) is $2.5^{\circ} \mathrm{C}$ (maximum $10.4^{\circ} \mathrm{C}$, minimum $-1.3^{\circ} \mathrm{C}$ ). Characteristic during this period are also diurnal fluctuations of temperature, as well as shorter or longer cycles, with average daily temperate above and below zero (Kejna 2008). It is known from other studies (Davey, Pickup, and Block 1992), that during sunny days, the soil surface can heat up to temperatures of $10-15^{\circ} \mathrm{C}$. The temperature of $22^{\circ} \mathrm{C}$ presented in the studies was treated as a control (optimal) for growth. None of the fungi examined in the research formed a macroscopically visible mycelium at a temperature of $0^{\circ} \mathrm{C}$. The most sensitive was $A$. flavus, which also did not develop mycelium at a temperature of $5^{\circ} \mathrm{C}$, and at a temperature of $10^{\circ} \mathrm{C}$, it reached a colony diameter of only $4 \mathrm{~cm}$. In a variant of the experiment with temporal freezing and thawing of the inoculum, most of the examined fungi survived freezing. The exception was A. flavus and G. candidum, except that $G$. candidum resumed growth after being transferred to a controlled temperature of $22^{\circ} \mathrm{C}$, which means that the inoculum also survived freezing. In the studies presented, the inoculum of $A$. flavus and G. candidum consisted of both mycelium fragments and spores. Vishniac (Vishniac 1996) believes that mycelium is more vulnerable to freezing than spores, which is why spores often survive even multiple cycles of freezing and thawing. The species $A$. flavus sporulates very abundantly under optimal conditions. At 
the time of inoculation of the medium, the inoculum was practically only spores. Despite this, A. flavus spores did not survive a single freeze cycle. Geotrichum, on the other hand, has a different mechanism for spore formation. Generally, it produces spores less abundantly, and they are formed at the ends of the hypha by fragmentation. In the case of G. candidum, there was probably more mycelium than spores in the inoculum, and yet G. candidum resumed growth after being frozen for a longer period of acclimatization and transfer to a higher temperature. In the freezing and thawing experiment variant, in the case of Penicillium sp., A. alterna$t a, C$. cladosporioides and B. cinerea, the mycelium did not differ macroscopically in appearance or colour from the control variants. In contrast, $T$. viride in the freezing and thawing variant has developed a very faint (delicate) mycelium with no signs of sporulation. Under normal conditions, T. viride forms white-green, fluffy colonies on agar media. This colour is given by the abundant formation of spores, while the vegetative mycelium is white or even transparent. T. viride did not produce spores in this variant of the experiment. Spores were also not found in B. cinerea, despite the normally macroscopic-looking mycelium. Loss of sporulation (Bertolini, and Tian 1996) and the formation of a periodically sterile mycelium (Robinson 2001) is one of the adaptive mechanisms for low temperatures. Another adaptation may be shortening of the life cycle, more abundant spore formation or, on the contrary, an extension of the life cycle. Bertolini, and Tian (Bertolini, and Tian 1996) observed in Penicillium hirsutum delayed spore germination at lower temperatures $\left(+4\right.$ to $\left.-4^{\circ} \mathrm{C}\right)$. The studies cited, did not compare the timing of the beginning of the spore production. However, it has been observed that at lower temperatures, spores were less abundant than at temperature of $22^{\circ} \mathrm{C}$, and some species such as G. candidum do not grow at temperature of 5 and $10^{\circ} \mathrm{C}$. Only $A$. alternata at temperature of $10^{\circ} \mathrm{C}$ produced more spores compared to the control.
Fungi of the genera Penicillium, Aspergillus, Alternaria, Cladosporium, Trichoderma, Geotrichum and Botrytis are widespread in nature. They are found in soil, on wood, on live plants, on plant and animal remains, on food products, on stored seeds and various organic substrates (Domsch, and Gams 1972; Fassatiová 1983). Also, they are considered to be cosmopolitan organisms, easily spreading and inhabiting various environments, including extremely cold ones, such as the polar regions (Marshall 1997; Gunde-Cimerman et al. 2003). To effectively colonize new environments, these organisms must be able to grow and reproduce in, or adapt to the new environment, in addition to having viable propagules and effective transport mechanisms (Ellis-Evans, and Walton 1990). Fungi in the genera of Cladosporium and Penicillium are classified as psychrophiles, while the other species studied have a much wider range of growth temperature. The fungi in the presented studies were able to develop at low temperatures. No growth at temperature of $0^{\circ} \mathrm{C}$ did not mean that it was a critical (lethal) temperature for them, as demonstrated by a variant of the experiment with temporal freezing of the inoculum to the temperature of $-15^{\circ} \mathrm{C}$ and subsequent thawing, as they were able to survive such a thermal shock. Fungi which did not begin their growth at $0^{\circ} \mathrm{C}$, or after freezing and thawing, when favourable thermal conditions appeared, resumed development, even after quite a long time from the beginning of the experiment, which proves their high viability and adaptation to new environmental conditions (Thammavongs, Panoff, and Guéguen 2000; Gocheva et al. 2006; Onofri et al. 2007). A. flavus proved to be the most sensitive of the examined fungi. Fungi in the genera of Aspergillus are one of the more thermophilic ones, with an optimal growth temperature of around $30-35^{\circ} \mathrm{C}$ (Shehu, and Bello 2011). In the studies presented, $A$. fla$v u s$ at lower temperatures $\left(0\right.$ to $\left.5^{\circ} \mathrm{C}\right)$ did not develop, while freezing and thawing was lethal for this species.

The unintentional transport of fungal spores along with people arriving at polar stations, whether these species are treated 
as alien or cosmopolitan, is a dangerous phenomenon because many of these species are potentially pathogenic for plants and warm-blooded organisms. Fungi introduced by man may be new pathogens to many native populations of Antarctic flora and fauna. Isolated populations of plants and animals in the polar regions are particularly vulnerable to infections, which can have disastrous consequences (Mercantini et al. 1993; Hoshino et al. 2001; Rogers, Starmer, and Castello 2004; Barbosa, and Palacios 2009; Grimaldi et al. 2014).

\section{Conclusions}

1. The fungi Penicillium sp., Alternaria alternata, Cladosporium cladosporioides, Trichoderma viride, Geotrichum candidum and Botrytis cinerea were able to develop at temperature of 5 and $10^{\circ} \mathrm{C}$, as well as after one cycle of freezing, down to $-15^{\circ} \mathrm{C}$ and thawing, up to $+10^{\circ} \mathrm{C}$.

2. The temperature of $0^{\circ} \mathrm{C}$ was not lethal for most of the examined fungi, except for Aspergillus flavus. At temperature of $0^{\circ} \mathrm{C}$ the fungi studied did not produce macroscopically visible mycelium, however, after being transferred to higher temperatures, they resumed growth even after quite a long time from the beginning of the experiment.

3. The most sensitive was A. flavus. At $5^{\circ} \mathrm{C}$, in contrast to the other tested fungi, it did not develop, whereas freezing and thawing were lethal for this species.

4. Temperature affected spore production. Species G. candidum at lower temperatures $\left(5\right.$ and $\left.10^{\circ} \mathrm{C}\right)$, while $T$. viride and $B$. cinerea after one freezing and thawing cycle did not produce spores, despite the development of mycelium.

\section{Bibliography}

Augustyniuk-Kram, Anna, Katarzyna J. Chwedorzewska, Małgorzata Korczak-Abshire, Maria Olech, and Maria Lityńska-Zając. 2013. "An analysis of fungal propagules transported to the Henryk Arctowski Station." Polish Polar Research 34(3): 269-278. https://doi.org/10.2478/popore-2013-0015.
Barbosa, Andrés, and Maria J. Palacios. 2009. "Health of Antarctic birds: a review of their parasites, pathogens and diseases." Polar Biology 32: 1095-1115. https://doi.org/10.1007/ s00300-009-0640-3.

Bertolini, Paolo, and Shiping P. Tian. 1996. "Low temperature biology and pathogenicity of Penicillium hirsutum on garlic in storage." Postharvest Biology and Technology 7(1-2): 83-89. https://doi.org/10.1016/09255214(95)00025-9.

Chwedorzewska, Katarzyna J., and Małgorzata Korczak. 2010. "Human impact upon the environment in the vicinity of Arctowski Station, King Georg Island, Antarctica." Polish Polar Research 31(1): 45-60. https://doi. org/10.4202/ppres.2010.04.

Convey, Peter, Roger S. Key, and Rosy J. D. Key. 2010. "The establishment of a new ecological guild of pollinating insects on sub-Antarctic South Georgia." Antarctic Science 22(5): 508-512. https://doi.org/10.1017/ S095410201000057X.

Chwedorzewska, Katarzyna J., Małgorzata Korczak-Abshire, Maria Olech, Maria Lityńska-Zając, and Anna Augustyniuk-Kram. 2013a. "Alien invertebrates transported accidentally to the Polish Antarctic Station on cargo and fresh foods." Polish Polar Research 34(1): 55-66. https://doi.org/10.2478/popore-2013-0005.

Chwedorzewska, Katarzyna J., Małgorzata Korczak-Abshire, Maria Olech, Maria Lityńska-Zając, and Anna Augustyniuk-Kram. 2013b. „Presja gatunków obcych na lądowe ekosystemy Morskiej Antarktyki." Kosmos 62(3): 351-358.

Davey, Martin C., Jon Pickup, and Wiliam Block. 1992. "Temperature variation and its biological significance in fellfield habitats on a maritime Antarctic island." Antarctic Science 4(4): 383-388. https://doi.org/10.1017/ S0954102092000567.

Domsch, Klaus H., and Walter Gams. 1972. Fungi in agricultural soils. New York: Halsted Press.

Ellis-Evans Cynan J., and David Walton. 1990. "The process of colonization in Antarctic terrestrial and freshwater ecosystems." Proceedings of the NIPR Symposium of Polar Biology 3: 151-163.

Fassatiová, Olga. 1983. Grzyby mikroskopowe w mikrobiologii technicznej. Warszawa:Wydawnictwo Naukowo-Techniczne. 
Gocheva, Yana G., Ekaterina Tz. Krumowa, Lyudmila S. Slokoska, Jeny G. Miteva, Spassen V. Vassiliev, and Maria B. Angelova. 2006. "Cell response of Antarctic and temperate strains of Penicillium spp. to different growth temperature." Mycological Research 110(11): 1347-1354. https://doi.org/10.1016/j.mycres.2006.08.007.

Gremmen, Nicolas J.M., and Valdon R. Smith. 1999. "New records of alien vascular plants from Marion and Prince Edward Islands, sub-Antarctic." Polar Biology 21: 401-409.

https://doi.org/10.1007/s003000050380.

Grimaldi, Wray W., Phil J. Seddon, Phil O’B. Lyver, Shinichi Nakagawa, and Daniel M. Tompkins. 2014. "Infectious diseases of Antarctic penguins: current status and future threats." Polar Biology 38(5): 591-606. https://doi.org/10.1007/s00300-014-1632-5.

Gunde-Cimerman, Nina, Silva Sonjak, Polona Zalar, Jens C. Frisvad, Børge Diderichsen, and Ana Plemenitaš. 2003. "Extremophilic fungi in arctic ice: a relationship between adaptation to low temperature and water activity." Physics and Chemistry of the Earth 28(2832): 1273-1278. https://doi.org/10.1016/j. pce.2003.08.056.

Hoshino, Tamotsu, Motoaki Tojo, Bo Chen, and Hiroshi Kanda. 2001. "Ecological impact of phytopathogenic fungi in Antarctic terrestrial flora." Folia Facultatis Scientiarum Naturalium Universitatis Masarykianae Brunensis, Geographia 25: 95-102.

Hughes, Kevin A., Jennifer E. Lee, Megumu Tsujimoto, Satoshi Imura, Dana M. Bergstrom, Chris Ware, Marc Lebouvier, Ad H.L. Huiskes, Niek J.M. Gremmen, Yves Frenot, Paul D. Bridge, and Steven L. Chown. 2011. "Food for thought: risks of non-native species transfer to the Antarctic region with fresh produce." Biological Conservation 144(5): 1682-1689. https://doi.org/10.1016/j. biocon.2011.03.001.

Hughes, Kevin A., and Roger M. Worland. 2010. "Spatial distribution, habitat preference and colonization status of two alien terrestrial invertebrate species in Antarctica." Antarctic Science 22(3): 221-231. https://doi. org/10.1017/S0954102009990770.

Huiskes, Ad H. L., Niek J. M. Gremmen, Dana M. Bergstrom, Yves Frenot, Kevin A.
Hughes, Satoshi Imura, Kate Kiefer, Marc Lebouvier, Jennifer E. Lee, Megumu Tsujimoto, Chris Ware, Bart van de Vijver, and Steven L. Chown. 2014. "Aliens in Antarctica: Assessing transfer of plant propagules by human visitors to reduce invasion risk." $B i$ ological Conservation 171: 278-284. https:// doi.org/10.1016/j.biocon.2014.01.038.

IAATO - Data \& Statistics. Dostęp 14. 06. 2016. https://iaato.org/information-resources/data-statistics/.

Kejna, Marek. 2008. "Topoclimatic conditions in the vicinity of the Arctowski Station (King George Island, Antarctica) during the summer season of 2006/2007." Polish Polar Research 29(2): 95-116.

Lityńska-Zając, Maria, Katarzyna J. Chwedorzewska, Maria Olech, Małgorzata Korczak-Abshire, and Anna Augustyniuk-Kram. 2012. "Diaspores and phyto-remains accidentally transported to the Antarctic Station during three expeditions." Biodiversity and Conservation 21:3411-3421. https://doi. org/10.1007/s10531-012-0371-6.

Maggi, Oriana, Solveig Tosi, Maria Angelova, Elisa Lagostina, Anna A. Fabbri, Lorenzo Pecoraro, Elisa Altobelli, Anna M. Picco, Elena Savino, Eva Branda, Benedetta Turchetti, Mirca Zotti, Alfredo Vizzini, and Pietro Buzzini. 2013. "Adaptation of fungi, including yeasts, to cold environments." Plant Biosystems 147(1): 247-258. https://doi.org/10.1 080/11263504.2012.753135.

Marshall, William A. 1997. "Seasonality in Antarctic airborne fungal spores." Applied and Environmental Microbiology 63(6): 2240-2245.

Mercantini, Rinaldo, Renato Marsella, Domenico Moretto, and Enrico Finotti. 1993. "Keratinophilic fungi in the Antarctic environment." Mycopathologia 122(3): 169-175. https://doi.org/10.1007/BF01103478.

Molina-Montenegro, Marco A., Fernando Carrasco-Urra, Ian Acuña-Rodríguez, Rómulo Oses, Cristian Torres-Díaz, and Katarzyna J. Chwedorzewska. 2014. "Assessing the importance of human activities for the establishment of the invasive Poa annua in Antarctica." Polar Research 33(1): 214-225. https://doi.org/10.3402/polar.v33.21425.

Olech, Maria, Michał Węgrzyn, Maja Lisowska, Katarzyna J. Chwedorzewska, i Agniesz- 
ka Słaby. 2013. „Polarne ekosystemy lądowe w kontekście zmian klimatycznych." Kosmos 62(3): 365-372.

Onofri, Silvano, Laura Selbmann, Gerrit S. de Hoog, Martin Grube, Donatella Barreca, Serena Ruisi, and Laura Zucconi. 2007. "Evolution and adaptation of fungi at boundaries of life." Advances in Space Research 40(11): 1657-1664. https://doi.org/10.1016/j.asr.2007.06.004.

Robinson, Clare H. 2001. "Cold adaptation in Arctic and Antarctic fungi." New Phytologist 151: 341-353. https://doi.org/10.1046/ j.1469-137.2001.00177.x.

Rogers, Scott O., William T. Starmer, and John D. Castello. 2004. "Recycling of pathogenic microbes through survival in ice." Medical Hypotheses 63(5): 773-777. https://doi. org/10.1016/J.MEHY.2004.04.004.

Ruisi, Serena, Donatella Barreca, Laura Selbmann, Laura Zucconi, and Silvano Onofri. 2007. "Fungi in Antarctica." Reviews in Environmental Science and Biotechnology 6(1): 127-141. https:// doi.org/10.1007/s11157-006-9107-y.

Russell, Nicholas J. 2008. "Membrane components and cold sensing. Fundamentals of Cold-Adapted Enzymes." In Psychrophiles: From biodiversity to biotechnology, edited by Rosa Margesin, Franz Schinner, JeanClaude Marx, and Charles Gerday, 177190. Berlin: Springer-Verlag. https://doi. org/10.1007/978-3-540-74335-4.
Shehu, Kasimu, and Muhammad T. Bello. 2011. "Effect of environmental factors on the growth of Aspergillus species associated with stored millet grains in Sokoto." Nigerian Journal of Basic and Applied Science 19(2): 218-223.

Thammavongs, Bouachanh, Jean-Michel Panoff, and Micheline Guéguen. 2000. "Phenotypic adaptation to freeze-thaw stress of the yeast-like fungus Geotrichum candidum." International Journal of Food Microbiology 60(1): 99-105. https://doi.org/10.1016/ s0168-1605(00)00374-3.

Turkiewicz, Marianna. 2006. „Drobnoustroje psychrofilne i ich biotechnologiczny potencjał." Kosmos 55(4): 309-312.

Vishniac, Helen S. 1996. "Biodiversity of yeast and filamentous microfungi in terrestrial Antarctic ecosystems." Biodiversity and Conservation 5: 1365-1378. https://doi.org/10.1007/ BF00051983.

Whinam, Jennie, Nicole Chilcott, and Dana M. Bergstrom. 2005. "Subantarctic hitchhikers: expeditioners as vector for the introduction of alien organisms." Biological Conservation 121(2): 207-219. https://doi.org/10.1016/j. biocon.2004.04.020. 